\title{
Natural radiation dose to Gammarus from Hudson River $\left(^{*}\right)$
}

\author{
A. S. PASCHOA (**) M. E. WRENN $(* *)$ \\ and M. EISENBUD (**)
}

(Manuscrit reçu le 11 octobre 1978)

\begin{abstract}
The purpose of this investigation is to evaluate the natural radiation dose rate to whole body and components of the Gammarus species, a zooplankton which occurs in the Hudson River among other places, and to compare the results with the upper limits of dose rates from man-made sources. The alpha dose rates to the exoskeleton and soft tissues are about 10 times the average alpha dose rate to the whole body, assuming uniform distribution of ${ }^{226} \mathrm{Ra}$. The natural alpha radiation dose rate to Gammarus represents only about 5 p. cent of the total natural dose to the organism, i. e., $492 \mathrm{mrad} / \mathrm{yr}$. The external dose rate due to ${ }^{40} \mathrm{~K},{ }^{238} \mathrm{U}$ plus daughters and ${ }^{232} \mathrm{Th}$ plus daughters accumulated in the sediments comprise $91 \mathrm{p}$. cent of that total natural dose rate, the remaining percentage being due to natural internal beta emitters and cosmic radiation. Man-made sources can cause an external dose rate up to $224 \mathrm{mrad} / \mathrm{yr}$, which comprises roughly $1 / 3$ of the total dose rate (up to $716 \mathrm{mrad} / \mathrm{yr}$; natural plus man-made) to the Gammarus of Hudson River in front of Indian Point Nuclear Power Station. However, in terms of doseequivalent the natural sources of radiation would contribute more than 75 p. cent of the total dose to Gammarus.
\end{abstract}

\section{RÉSUMÉ}

Le but de cette recherche est la détermination de la dose d'irradiation naturelle pour l'organisme entier, ainsi que pour certains organes de l'espèce Gammarus - un zooplancton du fleuve Hudson et d'autres milieux aquatiques - et la comparaison de ces résultats avec les limites supérieures des doses dues aux sources artificielles. Les doses alpha pour l'exosquelette et pour les tissus mous sont environ 10 fois supérieures à celles pour le corps entier, avec

$\left(^{*}\right)$ Presented at the 4th symposium on Hudson River ecology, Bear Mountain, New York March 26-39, 1976.

(**) Present address: Pontifícia Universidade Católica do Rio de Janeiro, Departamento de Física, C.P. 38071, Z.C. 19, Rio de Janeiro, 22453, Brasil.

$\left.{ }^{(* * *}\right)$ New York University Medical Center, 550 First Ave., New York 10016, U.S.A.

RADIOPROTECTION, VOL. 14 - 0033-8451/1979/99/\$ 4.00/C) Bordas-Dunod. 
l'hypothèse d'une distribution uniforme de ${ }^{226} \mathrm{Ra}$. La dose d'irradiation naturelle alpha pour Gammarus correspond seulement à environ $5 \mathrm{p}$. cent de la dose totale d'irradiation naturelle (492 mrad/an). La dose d'irradiation externe due à ${ }^{40} \mathrm{~K}$, à ${ }^{238} \mathrm{U}$ et à ${ }^{232} \mathrm{Th}$ y compris leurs descendants accumulés dans les sédiments correspond à $91 \mathrm{p}$. cent de la dose totale; le pourcentage restant correspond aux émetteurs bêta naturels internes, et au rayonnement cosmique. Les sources artificielles peuvent être responsables d'une dose externe allant jusqu'à $224 \mathrm{mrad} / \mathrm{an}$, laquelle comprend environ $1 / 3$ de la dose totale (due aux sources naturelles et artificielles et dont la valeur peut varier jusqu'à $716 \mathrm{mrad} / \mathrm{an}$ ) pour Gammarus vivant dans le fleuve Hudson en face de la centrale nucléaire d'Indian Point. Cependant, en terme d'équivalents de doses, les sources naturelles contribueraient pour plus de $75 \mathrm{p}$. cent de la dose totale pour le Gammarus.

\section{INTRODUCTION}

The investigation of the radiation dose to aquatic organisms under laboratory conditions and in the natural environment has been recognized by TEMPLETON et al. (1971) as an important subsidizer to establish a baseline for studies of the effects of radiation. Two main difficulties are related to the calculations of the dose rate from radionuclides absorbed by or adsorbed on aquatic organisms in general, and plankton in particular, as follows: (i) radionuclides are seldom distributed uniformly throughout the organisms; and (ii) the wide variation in the energy and type of emissions.

Using conventional dosimetry, CHERRY has assumed that $50 \mathrm{p}$. cent of the energy of alpha particles emitted in diatoms was absorbed within the organisms, without consideration neither of the distribution of alpha emitters nor the geometry of the phytoplankton diatom [3]. Later, SHANNON and CHERRY and SHANNON $[18,19]$ have assumed, in new dosimetric estimations, that $25 \mathrm{p}$. cent of the total energy of alpha particles emitted in a phytoplankton would be absorbed, while for the zooplankton nearly $100 \mathrm{p}$. cent would be absorbed, assuming in both cases undefined geometries for the organisms and uniform distribution of alpha emitters. Those somewhat arbitrary assumptions led to the indication that the natural radiation dose received by plankton might be higher than the estimations (i. e., between 40 and $620 \mathrm{mrad} / \mathrm{yr}$ from deep sea sediments) made earlier by Folsom and HarleY who assumed that the internal alpha dose rate to plankton would be negligible [5]. However, not until recently the first dosimetric model was introduced by WOODHEAD, to calculate the radiation dose to plankton [21].

The dosimetric model developed by WoODHEAD assumes that all phytoplankton species are represented by a sphere of unit density tissue $50 \mu \mathrm{m}$ density tissue $0.5 \mathrm{~cm}$ long and $0.2 \mathrm{~cm}$ diameter. Although WOODHEAD's model assumes these generalized geometries for phyto and zooplankton, it fails to discuss distributions of alpha emitters other than the uniform distribution throughout the entire volume of the geometric figures adopted. As a consequence, the dosimetric model developed by WOODHEAD is helpful to 
make general comparisons, but it is inadequate to calculate the alpha dose rate to any particular species of plankton.

A dosimetric model which takes into account the distribution of alpha emitters with aid of quantitative autoradiograph is described elsewhere [15], and it is applied here to calculate the internal alpha dose rate to selected components of Gammarus. The total (internal plus external) natural dose rate is calculated from direct measurements and then compared with the upper limits for external dose rate from man made sources in the area of the Hudson River where Gammarus have been collected.

\section{MEAN ALPHA ENERGY AVAILABLE POR DEPOSTION IN ORGANISMS FOLLOWING ACCUMULATION OF ${ }^{228} \mathrm{Ra}$ AND ${ }^{226} \mathrm{Ra}$}

The capacity of plankton to concentrate natural occurring radionuclides is reviewed elsewhere [16]. In particular, ${ }^{226} \mathrm{Ra},{ }^{228} \mathrm{Ra}$ have higher concentrations in plankton relatively to their concentrations in water. Tables I and II present the average concentrations of selected radionuclides from natural (including ${ }^{226} \mathrm{Ra},{ }^{228} \mathrm{Ra}$, and ${ }^{228} \mathrm{Th}$ ) and man-made origins in Gammarus of Hudson River.

The natural alpha dose rate to an organism depends, of course, on the alpha energy available for deposition within that organism. On the other hand, the alpha energy available for deposition is a function of the fraction of the gaseous radionuclides of the natural series, i. e., ${ }^{220} \mathrm{Rn}$ (thoron) and ${ }^{222} \mathrm{Rn}$ (radon) that escape from the organism, because they are both alpha emitters themselves and precursors of other alpha emitters as can be seen on Tables III and IV. Accordingly, for dosimetric purposes, it is necessary to know the mean alpha energy, $\bar{E}_{\mathrm{a} T}$ and $\bar{E}_{\mathrm{a} R}$, available for deposition within the organisms following uptake of ${ }^{228} \mathrm{Ra}$ and/or ${ }^{228} \mathrm{Th}$, and ${ }^{226} \mathrm{Ra}$ respectively, if the dosimetry is based on counting alpha tracks in autoradiographs [15].

The expression for $E_{a T}$ may be written as follows:

$$
\bar{E}_{\alpha T}=\sum_{i=1}^{2} E_{\alpha T-i}+\left(1-f_{T n}\right) \sum_{j=3}^{6} E_{\alpha T-j}
$$

where $E_{\mathrm{a} T-t}$ and $E_{\mathrm{a} T-\mathrm{j}}$ are the average alpha energies per disintegration of each radionuclide relevant in the ${ }^{228} \mathrm{Ra}$ chain of daughters, taking into account the frequency of emission for the particular energies; and $f_{T n}$ is the fraction of thoron gas escaping from the organism.

The half-life of thoron is only $55.3 \mathrm{~s}$ and the biological mechanisms of release ordinarily last hours, therefore, it is reasonable to hypothesize that $f_{T n}$ may be considered negligible, although little is still known about the amount of thoron and radon gases produced that escape from aquatic organisms after accumulation of ${ }^{228} \mathrm{Ra}$ and ${ }^{226} \mathrm{Ra}$, respectively. Thus, substituting $f_{T_{n}} \simeq 0$ into equation (1), the average alpha energy, $\bar{E}_{\mathrm{a} T}$, becomes

$$
E_{\alpha T} \simeq 31.9 \mathrm{MeV} \text {. }
$$

The rationale behind the approximation $f_{T_{n}} \simeq 0$ may be reinforced by keeping in mind that the exhalation of thoron produced in human beings depends on the nature of the internal contamination, and it ranges from $0.12 \mathrm{p}$. cent to $12 \mathrm{p}$. cent [7]. The mean alpha energy available for deposition per disintegration of ${ }^{228} \mathrm{Ra}$ and/or ${ }^{228} \mathrm{Th}$ calculated by equation (1) with $f_{T n}=0.12$ (i. e., by taking the upper limit of $12 \mathrm{p}$. cent of thoron escaping) is $28.7 \mathrm{MeV}$

vOL. $14-\mathrm{N}^{\circ} 2$ 


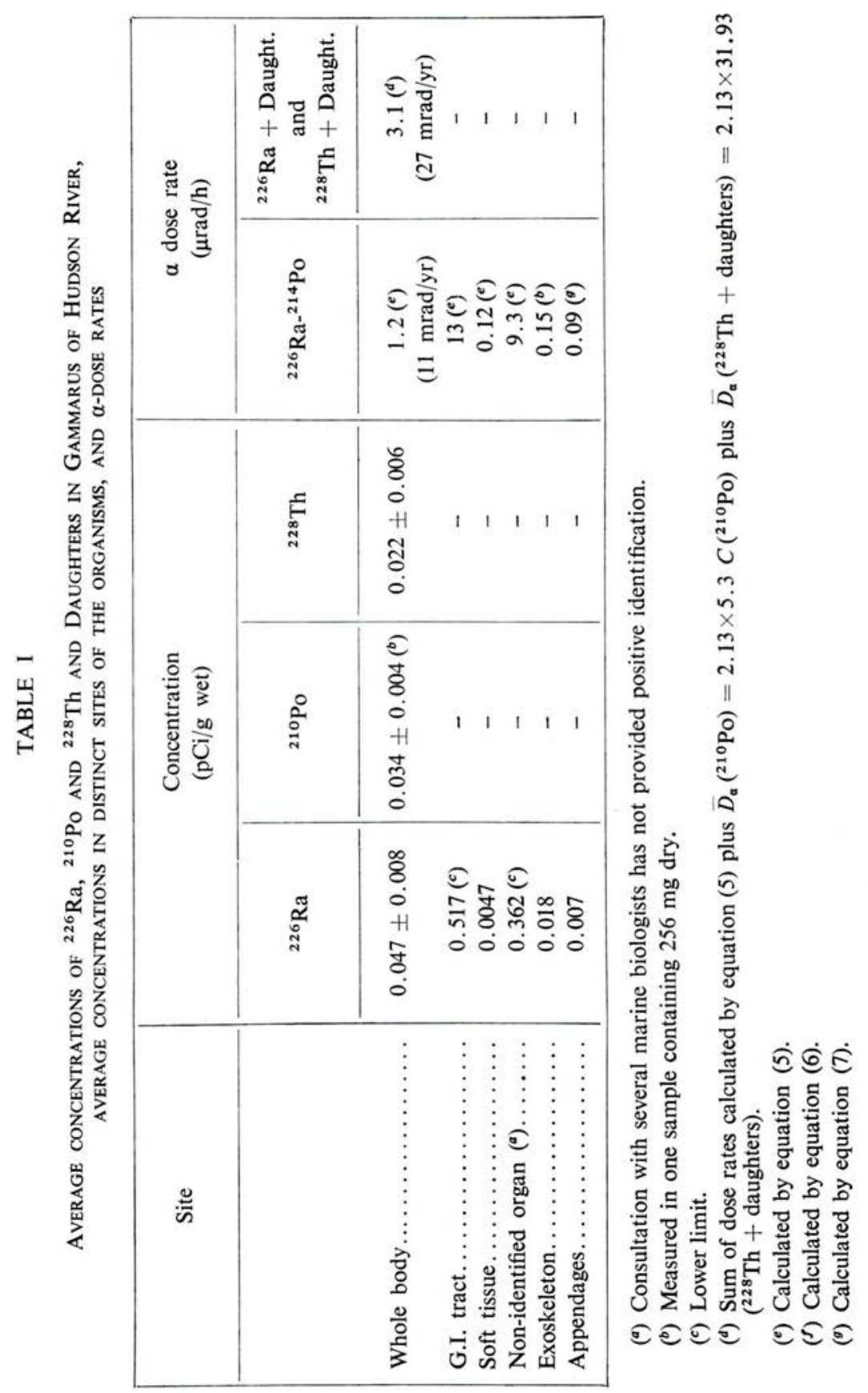




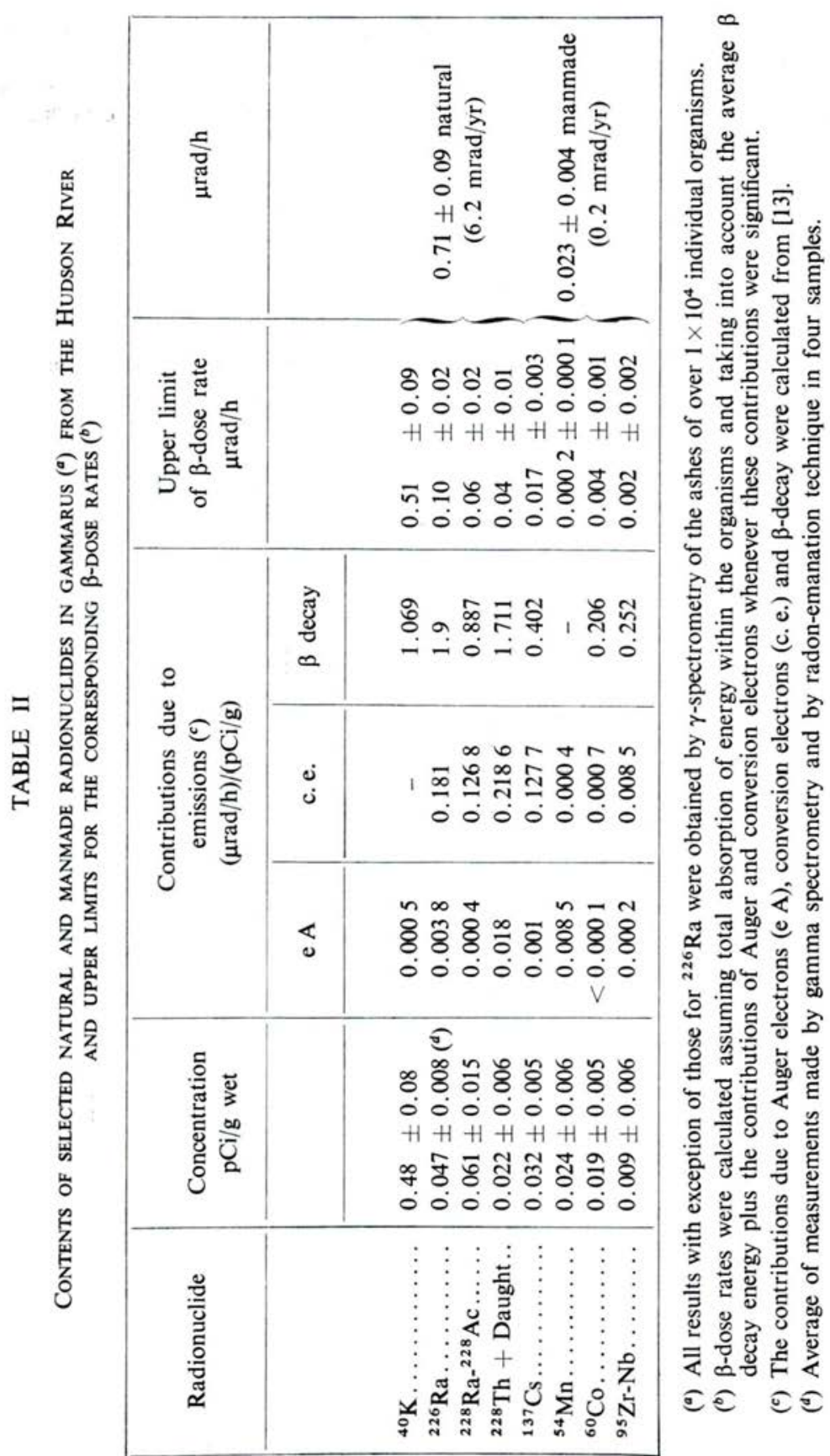


which represents about $90 \mathrm{p}$. cent of the mean alpha energy available for deposition with total thoron retention.

The dose rate to Gammarus due to concentration of ${ }^{226} \mathrm{Ra}$ is mainly due to the alpha disintegration of ${ }^{226} \mathrm{Ra}$ itself plus the alpha disintegration of its daughter products through ${ }^{214} \mathrm{Po}$, since the ingrowth of ${ }^{210} \mathrm{Po}$ is slowed by the long half-life of ${ }^{210} \mathrm{~Pb}(21$ years). Ana-

TABLE III

URANIUM SERIES

\begin{tabular}{|c|c|c|c|c|c|}
\hline \multirow{2}{*}{ Radionuclide } & \multirow{2}{*}{ Half-life } & \multicolumn{4}{|c|}{ Energies of emissions $(\mathrm{MeV})$ and intensities $(\%)$} \\
\hline & & $\alpha$ & $\beta$ & & $\gamma$ \\
\hline 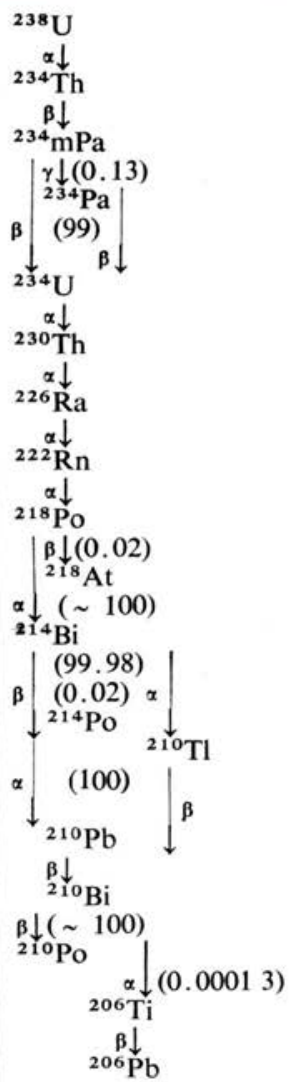 & $\begin{array}{c}4.51 \times 10^{9} \mathrm{yr} \\
24.1 \mathrm{~d} \\
1.17 \mathrm{~m} \\
6.75 \mathrm{~h} \\
2.47 \times 10^{5} \mathrm{yr} \\
8.0 \times 10^{4} \mathrm{yr} \\
1602 \mathrm{yr} \\
3.823 \mathrm{~d} \\
3.05 \mathrm{~m} \\
\sim 2 \mathrm{~s} \\
19.7 \mathrm{~m} \\
164 \mathrm{~s} \\
1.3 \mathrm{~m} \\
21 \mathrm{yr} \\
5.01 \mathrm{~d} \\
138.4 \mathrm{~d} \\
4.19 \mathrm{~m} \\
5 t a b l e\end{array}$ & 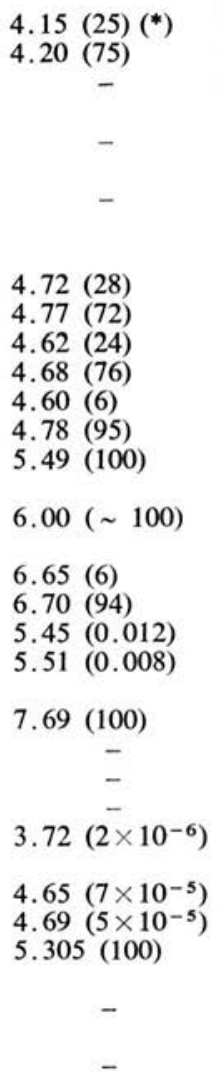 & 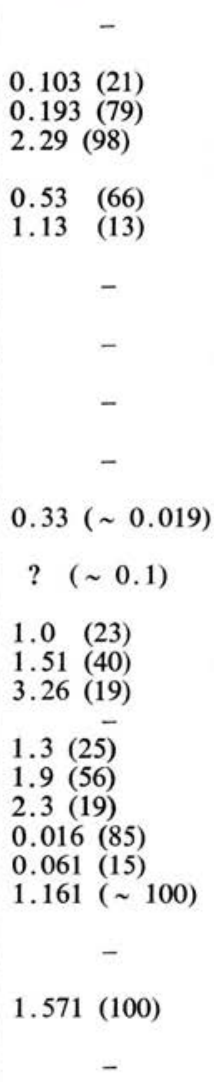 & $\begin{array}{l}0.063 \\
0.093 \\
0.765 \\
1.001 \\
0.100 \\
0.70 \\
0.90 \\
0.053 \\
\\
0.068 \\
0.142 \\
0.186\end{array}$ & $\begin{array}{l}- \\
- \\
(47) \\
(17) \\
(17) \\
(0.014) \\
(80) \\
(100) \\
(21) \\
(4) \\
- \\
(0.0011) \\
- \\
-\end{array}$ \\
\hline
\end{tabular}

(*) Numbers between brackets indicate intensity in p. cent. Based on data from [9]. 
TABLE IV

THORIUM SERIES

\begin{tabular}{|c|c|c|c|c|}
\hline \multirow{2}{*}{ Radionuclide } & \multirow{2}{*}{ Half-life } & \multicolumn{3}{|c|}{ Energies of emissions $(\mathrm{MeV})$ and intensities $(\%)$} \\
\hline & & $\alpha$ & $\beta$ & $\gamma$ \\
\hline 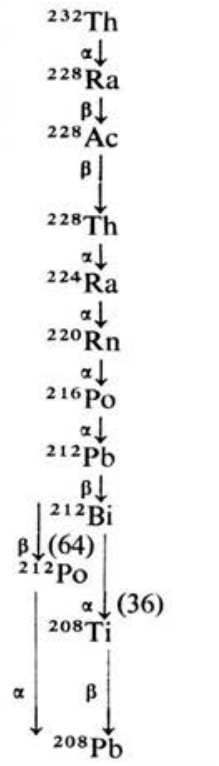 & $\begin{array}{c}1.41 \times 10^{10} \mathrm{yr} \\
6.7 \mathrm{yr} \\
6.13 \mathrm{~h} \\
1.910 \mathrm{yr} \\
3.64 \mathrm{~d} \\
5 \mathrm{~s} \\
0.15 \mathrm{~s} \\
10.64 \mathrm{~h} \\
60.6 \mathrm{~m} \\
304 \mathrm{~ns} \\
3.10 \mathrm{~m}\end{array}$ & $\begin{array}{c}3.95(24)\left({ }^{a}\right) \\
4.01(76) \\
\quad- \\
- \\
5.34(28) \\
5.43(71) \\
5.45(6) \\
5.68(94) \\
6.29(100)\end{array}$ & $\begin{array}{c}0.055(100) \\
1.18 \quad(35) \\
1.75 \quad(12) \\
2.09 \quad(12) \\
- \\
- \\
- \\
- \\
- \\
0.346(81) \\
0.586(14) \\
1.55 \quad(5) \\
2.26 \quad(55) \\
- \\
1.28 \quad(25) \\
1.52 \quad(21) \\
1.80 \quad(50) \\
- \\
-\end{array}$ & \begin{tabular}{l}
\multicolumn{1}{c}{-} \\
$0.34(15)$ \\
$0.908(25)$ \\
$0.96(20)$ \\
$0.084(1.6)$ \\
$0.214(0.3)$ \\
$0.241(3.7)$ \\
$0.55 \quad(0.07)$ \\
$\quad-$ \\
$\quad$ \\
$0.239(47)$ \\
$0.300(3.2)$ \\
$0.040(2)$ \\
$0.727(7)$ \\
$1.620(1.8)$
\end{tabular} \\
\hline
\end{tabular}

${ }^{(a)}$ Numbers between brackets indicate intensity in p. cent. Based upon data from [9].

logically to the preeceding case, the mean alpha energy, $E_{a R}$ available for deposition within the organism following uptake of ${ }^{226} \mathrm{Ra}$ may be expressed as follows:

$$
E_{\alpha R}=E_{\alpha R-1}+\left(1-f_{R n}\right) \sum_{k=2}^{4} E_{\alpha R-k}
$$

where $E_{\alpha R-1}$ and $E_{\alpha R-k}$ are the average alpha energies per disintegration of ${ }^{226} \mathrm{Ra}$ and its daughter products through ${ }^{214} \mathrm{Po}$, respectively, taking into account the frequency of emissions for the particular energies; and $f_{R n}$ is the fraction of radon gas escaping from the organism.

The half-life of radon gas is 3.82 days, hence the reasoning made earlier for thoron cannot be applied for radon. Therefore, the fraction, $f_{R n}$, of radon gas produced inside a Gammarus that escapes from the organism ought to be known in order to calculate the mean alpha energy available for deposition within the organism after accumulation of ${ }^{226} \mathrm{Ra}$. Laboratory experiments were set up to determine the fraction, $f_{R n}$, of radon that escapes from Gammarus previously labelled with ${ }^{226} \mathrm{Ra}$ [14]. The mean fraction of radon escaping from

vol. $14-\mathrm{N}^{\circ} 2$ 
the labelled organism is $\vec{f}_{R n}=0.62 \pm 0.09\left(^{1}\right)$ with a range from $0.425 \pm 0.003$ to $0.84 \pm 0.01$.

Thus substituting $\bar{f}_{R n}=0.62$ in place of $f_{R n}$ into equation (3), the mean energy, $E_{a R}$, available for deposition in Gammarus following uptake of ${ }^{226} \mathrm{Ra}$ is:

$$
\bar{E}_{\alpha R}=12.1 \mathrm{MeV} \text {. }
$$

\section{THE AMPHIPOD Gammarus OCCURING IN THE HUDSON RIVER}

The macrozooplankton, Gammarus, most usually collected in the Hudson River estuary is G. tigrinus [8]; however, G. fasciatus and G. daiberi are also likel yto occur in the Hudson riber. According to BousfielD, strictly fresh water amphipods like $G$. fasciatus may be washed into estuaries or even into marine habitats, but oligohaline brackish amphipods as Gammarus tigrinus and Gammarus daiberi, for example are seldom found in full marine salinities [1].

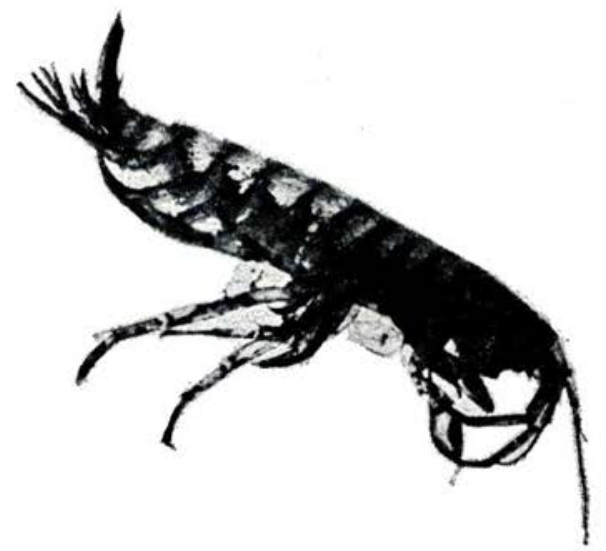

Photograph of a typical Gammarus from Hudson river $(\mathrm{G} \times 11)$

The Gammarus spp. living in the Hudson River estuary constitute important food in the diet of many species of fish inhabiting the estuary. On the other hand, Gammarus eat bacteria, phytoplankton, other zooplankton, and also practice cannibalism.

The average life span of Gammarus in the Hudson River estuary is believed to be less than one year, because most of the adult population is consumed by other animals before growing old. However, 15 months is an acceptable upper limit for the lifetime of Gammarus in the Hudson River.

A magnified photograph $(\mathrm{G} \times 11)$ of a typical Gammarus of the Hudson River estuary is shown below. The total average weight of a mixture of adult and young adult organisms was found to be $\left[5.2 \pm 1.5\left({ }^{2}\right)\right] \mathrm{mg}$ wet by weighing 77 organisms. The average percentage of water in 70 organisms was $(70 \pm 6) \mathrm{p}$. cent. The distribution of mass throughout the

(1) $1 \sigma$ due to propagation of errors associated with statistical counting only.

( $\left.{ }^{2}\right) 1 \sigma$. 
body has been determined and it is given in Table V. Soft-tissue plus water comprise $(74 \pm 8)$ p. cent, exoskeleton $(20 \pm 5)$ p. cent, and the appendages only $(6 \pm 3)$ p. cent.

A detailed morphological description of the genus Gammarus is presented elsewhere [14].

\section{RESULTS AND DISCUSSION}

The alpha dose rates from radium to the whole body and distinct sites of Gammarus of Hudson River were calculated based on counting alpha tracks in autoradiographs [15]. The alpha dose rates for the whole body, G.I. tract, soft tissue, and a non-identified organ have been calculated on the basis of uniform distribution of ${ }^{226} \mathrm{Ra}$. The range of a $5.64 \mathrm{MeV}$ alpha particle in tissue-like media is about $40 \mu \mathrm{m}$, which is shorter than the diameters of the organs considered, and corresponds to about $3 \mathrm{p}$. cent the average diameter of Gammarus [6]. Accordingly, it is assumed that the mean alpha energy available for deposition per disintegration of ${ }^{226} \mathrm{Ra}$ (or ${ }^{210} \mathrm{Po}$,

TABLE $V$

Weight Distribution in Gammarus

\begin{tabular}{|c|c|}
\hline Part of Organisms & Percentage \\
\cline { 1 - 2 } Soft tissue and water $\left({ }^{a}\right) \ldots \ldots \ldots$ & $74 \pm 8\left(^{b}\right)$ \\
Exoskeleton $\ldots \ldots \ldots \ldots \ldots \ldots \ldots$ & $20 \pm\left(^{\circ}\right)$ \\
Appendages $\left({ }^{c}\right) \ldots \ldots \ldots \ldots \ldots$ & $6 \pm 3$ \\
\hline
\end{tabular}

(a) The water percentage of total weight in 70 organisms was $(70 \pm 6 \%$ with $1 \sigma$.

${ }^{(b)}$ Indicates the approximate range for 10 organisms.

$\left.{ }^{(}\right)$Including Telson

or ${ }^{228} \mathrm{Th}$ plus daughters, as the case may be) is totally absorbed in the media. The alpha dose rate is then expressed as follows:

$$
\bar{D}_{\alpha}=25,7 \bar{C},
$$

where $D_{\alpha}$ is in $\mu \mathrm{rad} / \mathrm{hr}$.; and $\bar{C}$ is the average concentration of ${ }^{226} \mathrm{Ra}$ (in $\mathrm{pCi}^{226} \mathrm{Ra} / \mathrm{g}$ ) in the whole body or a particular organ of Gammarus.

Only $32 \mathrm{p}$. cent of the energy of alpha particles emitted from the atoms of ${ }^{226} \mathrm{Ra}$ plus daughters deposited in the exoskeleton of Gammarus will be delivered to the border layer internally adjacent to the Gammarus surface [15]. Thus, the average alpha dose rate to the exoskeleton can be expressed as

$$
\begin{aligned}
\bar{D}_{\alpha} & =25.7(0.32) \bar{C}, \\
& =8.2 \bar{C} .
\end{aligned}
$$

vOL. $14-\mathrm{N}^{\circ} 2$ 
The percentage of alpha energy emitted that is retained in the appendage is $48 \mathrm{p}$. cent [15]. Thus, the average alpha dose rate to the exoskeleton can be expressed by:

$$
\begin{aligned}
\bar{D}_{\alpha} & =25.7(0.48) \bar{C}, \\
& =12.3 \bar{C} .
\end{aligned}
$$

The average concentrations of alpha emitters in different sites of Gammarus of the Hudson River, where a quasi-steady state situation is assumed to prevail, were estimated based on short term studies on the accumulation of ${ }^{226} \mathrm{Ra}$ plus daughters in Gammarus under laboratory conditions [14]. Thus this restriction must be kept in mind when using the values for the alpha dose rate for distinct sites of Gammarus.

Table I shows the average concentrations of ${ }^{226} \mathrm{Ra}$ in the whole body and distinct sites of Gammarus of Hudson River, as well as the average concentrations of ${ }^{210} \mathrm{Po}$ and ${ }^{228} \mathrm{Th}$ plus daughters, and the corresponding alpha dose rates. The alpha dose rate to the G.I. tract from ${ }^{226} \mathrm{Ra}$ plus daughters, excluding ${ }^{210} \mathrm{Po}$, is $13 \mu \mathrm{rad} / \mathrm{h}$ (i. e., $\sim 0.11 \mathrm{rad} / \mathrm{yr}$ ). This dose rate is about 4 times higher than the alpha dose rate to the whole body due to ${ }^{226} \mathrm{Ra}$ plus daughters and ${ }^{228} \mathrm{Th}$ plus daughters (see Table I). Nevertheless, that alpha dose rate to the G.I. tract is only about half the annual external dose received by Gammarus from ${ }^{40} \mathrm{~K}$ in sediments, as it can be seen in Table VIII. The G.I. tract should be considered as the "critical" organ for Gammarus because: (i) alpha emitters from the thorium series may contribute as high as twice that contribution from ${ }^{226} \mathrm{Ra}$ plus daughters to the alpha dose rate to the G.I. tract when both ${ }^{228} \mathrm{Th}$ and ${ }^{226} \mathrm{Ra}$ are found to have similar activity concentrations; and (ii) the dose equivalent (in terms of mrem/yr) has an enhancing quality factor for alpha particles, while ${ }^{40} \mathrm{~K}$ (which contributes significantly to the external dose rate according to Table VIII, because of its presence in the sediments), is only a beta-gamma emitter. However, the concentration of ${ }^{228} \mathrm{Th}$ in the G.I. tract of Gammarus is still to be determined, although ${ }^{228} \mathrm{Th}$ is an important potential contributor to local alpha dose rates.

Hot spots of alpha emitters in soft tissue and exoskeleton may receive alpha dose rates 18 times higher than the average dose rates to soft tissues. However, those hot spots are believed to change sites within the organism as a function of time, thus the localized dose rates to hot spots may be meaningless, unless the average dose rate throughout the path of these hot spots can also be estimated.

The contents of ${ }^{226} \mathrm{Ra},{ }^{228} \mathrm{Ra},{ }^{228} \mathrm{Th},{ }^{40} \mathrm{~K}$ and selected man-made radionuclides in Gammarus of Hudson River are listed in Table II, with the corresponding upper limits for beta dose rates. These upper limits were calculated by using LOEVINGER's approach [11] and including contributions from Auger-and conversion-electrons whenever those emissions might contribute significantly to the total beta dose rate. The conversion electrons from manmade ${ }^{137} \mathrm{Cs}$ contribute over $20 \mathrm{p}$. cent to the beta dose per $\mathrm{pCi}{ }^{137} \mathrm{Cs} / \mathrm{g}$ wet, while the Auger-plus conversion-electrons from the natural series emitters have contributions to the beta dose rate per $\mathrm{pCi} / \mathrm{g}$ wet 
approximately as follows (see Table II): 12 p. cent (from ${ }^{228} \mathrm{Ra}^{228} \mathrm{Ac}$ ); 12 p. cent (from ${ }^{228} \mathrm{Th}$ plus daughters); and $9 \mathrm{p}$. cent (from ${ }^{226} \mathrm{Ra}^{214} \mathrm{Po}$ ). The upper limits of the internal beta dose rates from man-made radionuclides to Gammarus of Hudson River near Indian Point is only 3.2 p. cent of the internal beta dose rates from natural radionuclides.

The contribution from internal gamma radiation to the total dose rate may be regarded as negligible, because it would be about 3 orders of magnitude lower than other component contributions to the total dose rate to Gammarus. The internal gamma-dose rate to zooplankton has been approached by WOODHEAD through the following equation developed by LOEVINGER et al., $[11$, p. 853]:

$$
\bar{D}_{\gamma}=\Gamma C \rho_{\mathrm{o}} \bar{g} \times 10^{-3} \mu \mathrm{rad} / \mathrm{h}
$$

where: $\Gamma$, is the specific gamma-ray constant in $\mathrm{cm}^{2} . \mathrm{rad} / \mathrm{h} . \mathrm{mCi} ; C$, is the activity concentration in $\mathrm{pCi} / \mathrm{g} ; \rho_{0}$, is the density of the organism in $\mathrm{g} / \mathrm{cm}^{3}$; and $\bar{g}$ is the mean geometrical factor in centimeters.

Formulas for $\Gamma$ and $\bar{g}$ have been first derived by MARINELli et al. [12]. Values for $\Gamma$ at several gamma energies are tabulated by LOEVINGER et al. $[11$, p. 889 and 904$]$. Thus the internal gamma dose rates to Gammarus can be easily calculated by placing $\bar{g}=0.86 \mathrm{~cm}[14$, appendix III] for Gammarus, but it is not included in Table II, because the values are too low as compared to the beta dose rates.

Table VI shows the average concentrations of natural and selected man-made radionuclides in sediments of Hudson River at Indian Point in the biennium 1969-1970 and in the years 1972 and 1973. The average concentrations of selected man-made radionuclides shown in Table VI are calculated from measurements of samples taken from the section of Hudson River in front of Indian Point Nuclear Power Plants, thus representing averages calculated only with the maximum values of concentrations of man-made radionuclides in sediments. Potassium 40 itself presents specific activity in the sediments more than twice the sum of specific activities of all other gamma emitting radionuclides listed in Table VI.

In order to calculate the dose rate received by Gammarus from radionuclides in the sediments of Hudson River in front of Indian Point, the following assumptions have been made:

(i) radionuclides are uniformly distributed in an infinite slab of sediment;

(ii) ${ }^{238} \mathrm{U}$ is in equilibrium with daughters in sediment of Hudson River; River;

(iii) ${ }^{232} \mathrm{Th}$ is also in equilibrium with daughters in sediment of Hudson

(iv) Gammarus spend half day at sediment surface;

(v) the contribution of natural gamma emitters in the sediments to the exposure rate at 1 meter above sediment surface is about $1 / 2$ of that contribution at sediment surface.

These assumptions were incorporated into the approximate expression presented by LENTSCH to calculate external dose rates at sediment surface [10].

vOL. $14-\mathrm{N}^{\circ} 2$ 
TABLE VI

Average Concentations of natural and Selected manmade Radionuclides IN SEDIMENTS OF HUdSON RIVER IN FRONT OF INDIAN POINT

\begin{tabular}{|c|c|c|c|}
\hline \multirow{2}{*}{ Radionuclide } & \multicolumn{3}{|c|}{ pCi dry } \\
\hline & $\begin{array}{c}(53)\left({ }^{a}\right) \\
1969-1970\left(^{b}\right)\end{array}$ & $\begin{array}{c}(6) \\
1972\left(^{c}\right)\end{array}$ & $\begin{array}{c}(19) \\
1973\left(^{d}\right)\end{array}$ \\
\hline${ }^{40} \mathrm{~K} \ldots \ldots \ldots \ldots$ & $18 \pm 2$ & $19 \pm 2$ & $17 \pm 2$ \\
\hline${ }^{226} \mathrm{Ra} \ldots \ldots \ldots$ & $0.91 \pm 0.07$ & - & - \\
\hline${ }^{232} \mathrm{Th} . . . \ldots \ldots$ & $1.20 \pm 0.1$ & & - \\
\hline${ }^{137} \mathrm{Cs} \ldots \ldots \ldots$ & $2.1 \pm 1.9$ & $2.7 \pm 1.9$ & $3.3 \pm 1.8$ \\
\hline${ }^{134} \mathrm{Cs} \ldots \ldots \ldots$ & $0.9 \pm 1.4$ & $3.9 \pm 3.7$ & $1.1 \pm 0.8$ \\
\hline${ }^{54} \mathrm{Mn} . \ldots \ldots \ldots$ & $0.58 \pm 0.58$ & $2.5 \pm 3.1$ & $0.21 \pm 0.18$ \\
\hline${ }^{60} \mathrm{Co} \ldots \ldots \ldots$ & $0.52 \pm 0.51$ & $1.3 \pm 1.0$ & $0.48 \pm 0.47$ \\
\hline${ }^{58} \mathrm{Co} \ldots \ldots \ldots$ & $0.06 \pm 0.32$ & $0.13 \pm 0.34$ & - \\
\hline${ }^{95} \mathrm{Zr}-\mathrm{Nb} \ldots \ldots \ldots$ & $0.32 \pm 0.63$ & - & - \\
\hline${ }^{144} \mathrm{Ce} . \ldots \ldots \ldots$ & $0.55 \pm 0.52$ & - & - \\
\hline
\end{tabular}

$\left({ }^{a}\right)$ Parentheses indicate the number of samples. $\left({ }^{b}\right)$ Data taken from [10].

(c) Data taken from [22]. $\left({ }^{d}\right)$ Data taken from [23].

Accordingly, the contribution to the external dose rate due to. beta and gamma emitters at sediment surface is given by the following expression:

$$
\bar{D}_{s s} / \bar{C}_{s}=4.67\left(\bar{E}_{\beta}+\bar{E}_{\gamma}\right)
$$

where $D_{s s}=$ average dose rate at sediment surface, $\mathrm{mrad} / \mathrm{yr} ; C_{s}=$ average concentration of radionuclide in the sediment, pCi/g dry, $\bar{E}_{\beta}=$ average beta energy, $\mathrm{MeV} / \mathrm{dis}$, and $\bar{E}_{\gamma}=$ average gamma energy, $\mathrm{MeV} / \mathrm{dis}$.

Equation (9) associated with the decay characteristics presented in [13] has been used to calculate the contributions per $\mathrm{pCi} / \mathrm{g}$ dry of natural and selected man-made radionuclides found in sediments to the external dose rate to Gammarus at sediment surface and at $1 \mathrm{~m}$ above the sediment surface. Table VII presents the value of these contributions.

Using data from Tables VI and VII, the annual dose rates to Gammarus of Hudson River living in the vicinity of Indian Point have been evaluated for periods of time to which the average concentrations of radionuclides in sediments were available. The results of such evaluations are shown in Table VIII. From Table VIII it can be seen that in the biennium 1969-1970 the average annual external dose to Gammarus from man-made radionuclides was about $50 \mathrm{p}$. cent of the external dose from natural emitters in the sediments. 
TABLE VII

CONTRIBUTION OF NATURAL AND SELECTED MAN-MADE RADIONUCLIDES TO THE EXTERNAL DOSE RATE TO GAMMARUS ASSUMING AN INFINITE SLAB OF SEDIMENT CONTAINING UNIFORMLY DISTRIBUTED RADIONUCLIDES $\left({ }^{a}\right)$

\begin{tabular}{|c|c|c|c|}
\hline \multirow{3}{*}{ Radionuclide } & \multicolumn{3}{|c|}{$(\mathrm{mrad} / \mathrm{yr}) /(\mathrm{pCi} / \mathrm{g}$ dry $)$} \\
\hline & \multicolumn{2}{|c|}{ At sediment surface } & \multirow{2}{*}{$\begin{array}{c}\text { At } 1 \mathrm{~m} \\
\text { Above } \\
\text { sediment } \\
\text { surface }\end{array}$} \\
\hline & $\gamma$ & $\beta$ and $\gamma$ & \\
\hline${ }^{40} \mathrm{~K} \quad \ldots \ldots \ldots \ldots \ldots$ & 3.7 & 13 & $1.9\left({ }^{b}\right)$ \\
\hline${ }^{238} U+$ Daughters. . . . . . & 23 & 66 & $12\left(^{b}\right)$ \\
\hline${ }^{232} \mathrm{Th}+$ Daughters...... & 44 & 70 & $22\left(^{b}\right)$ \\
\hline${ }^{137} \mathrm{Cs} \ldots \ldots \ldots \ldots \ldots \ldots$ & 13 & 18 & 8.3 \\
\hline${ }^{134} \mathrm{Cs} \ldots \ldots \ldots \ldots \ldots \ldots$ & 37 & 41 & 21 \\
\hline${ }^{54} \mathrm{Mn} \ldots \ldots \ldots \ldots \ldots$ & 20 & 20 & 11 \\
\hline${ }^{60} \mathrm{Co} \ldots \ldots \ldots \ldots \ldots \ldots$ & 58 & 60 & 33 \\
\hline${ }^{58} \mathrm{Co} \ldots \ldots \ldots \ldots \ldots$ & 23 & 24 & 11 \\
\hline${ }^{95} \mathrm{Zr}-\mathrm{Nb} \ldots \ldots \ldots \ldots \ldots$ & 56 & 61 & 33 \\
\hline${ }^{144} \mathrm{Ce}+$ Daughters ..... & 0.92 & 26 & 0.70 \\
\hline
\end{tabular}

(a) Values based on LENTSCH [10] assuming that Gammarus spend half day at sediment surface and half day at $1 \mathrm{~m}$ above the sediment surface.

(b) Assuming half of the contribution at sediment surface.

Assuming that the external annual dose rates to Gammarus from the natural series for the years 1972 and 1973 remained the same as they were in the biennium 1969-1970, it may be observed that the annual external dose rate from man-made sources in the sediments in 1972 was about the same as the external dose rate from natural sources, while in 1973 the dose rate dropped again to the 1969-1970 level. These results are in agreement with the earlier estimated dose to benthos in the vicinity of Indian Point made by WRENN et al. [24].

The total dose rates to Gammarus of Hudson River near Indian Point from natural and selected man-made sources are presented in Table IX, under the assumption that the external dose rates for the biennium 1969-1970 represent the ordinary levels in the Hudson River in front of Indian Point. The values of internal alpha and beta dose rates have been taken from Tables I and II, respectively.

voL. $14-\mathrm{N}^{\circ} 2$ 


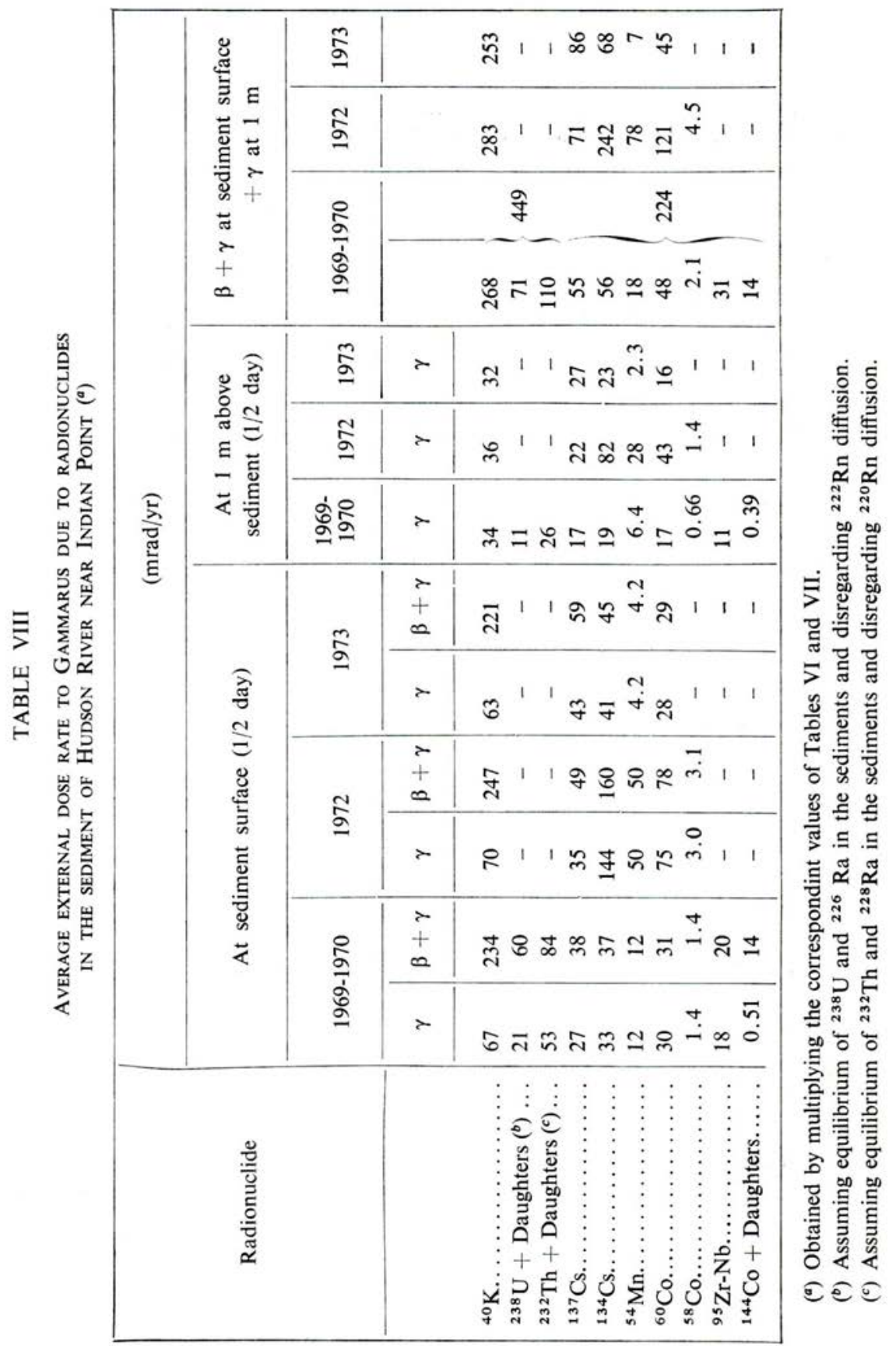


TABLE IX

Dose rates to Gammarus of Hudson River near Indian Point FROM NATURAL AND SELECTED MAN-MADE SOURCES OF RADIATION

\begin{tabular}{|c|c|c|c|}
\hline \multirow[b]{2}{*}{ Source of Radiation } & \multicolumn{3}{|c|}{$(\mathrm{mrad} / \mathrm{yr})$} \\
\hline & Natural & Man-made & $\begin{array}{c}\text { Natural } \\
\text { plus } \\
\text { Man-made }\end{array}$ \\
\hline Internal alpha $\ldots \ldots \ldots \ldots \ldots$ & 27 & - & 27 \\
\hline Internal beta $\left({ }^{a}\right) \ldots \ldots \ldots \ldots \ldots$ & 6.2 & 0.2 & 6.4 \\
\hline External $\ldots \ldots \ldots \ldots \ldots \ldots \ldots$ & 449 & 224 & 673 \\
\hline Cosmic radiation. ............ & $10\left({ }^{b}\right)$ & - & 10 \\
\hline TOTAL $\ldots \ldots \ldots \ldots \ldots \ldots$ & 492 & 224 & 716 \\
\hline
\end{tabular}

$\left({ }^{a}\right)$ Upper limits assuming total absorption of beta radiation within Gammarus.

(b) Assuming constant exposure at a depth $(\sim 10 \mathrm{~m})$ corresponding to $1 / e$ of the dose rate of $28 \mathrm{mrad} / \mathrm{yr}$ at sea level [4, p. 194].

The dose rate due to cosmic radiation has been estimated, assuming a value corresponding to $1 / e$ of the dose rate at sea level $[4, p .194]$. The dose rate from radionuclides in water has been neglected because the concentrations of both natural and man-made radionuclides in water are at least 2 orders of magnitude lower than those concentrations in Gammarus.

\section{CONCLUSIONS}

The total external dose rate of $673 \mathrm{mrad} / \mathrm{yr}(449 \mathrm{mrad} / \mathrm{yr}$ from natural sources) received by Gammarus from radionuclides in the sediments of Hudson River is in general agreement with the dose estimations made earlier by Folsom and HARLEY [5], who put between 40 and $620 \mathrm{mrad} / \mathrm{yr}$ the dose rate from deep sea sediments when ${ }^{40} \mathrm{~K}$ is the only contributor. The combined radiations of natural and man-made radionuclides in sediments cause $95 \mathrm{p}$. cent of the total (internal plus external) radiation dose rate received by Gammarus of Hudson River in front of Indian Point.

The inescapable conclusion inferred from Table IX is that low level radioactivity releases from a long time operating nuclear power station located at Indian Point do not increase significantly the dose rate received by Gammarus from natural sources and from radionuclides produced in weapon-tests. It appears safe to suppose, to a first approximation, that benthic organisms are subject to higher dose rates from both natural and man-made sources deposited in the sediments than other marine organisms. 
The alpha dose rate from radium to the G.I. tract of Gammarus may be 1 to 2 orders of magnitude higher than the natural alpha dose rate to the whole body. Therefore, the G.I. tract should be considered the "critical organ" for Gammarus, and further studies should be undertaken to determine the dose to the G.I. tract of zooplankton from man-made alpha emitters.

The dose rate from internal alpha emitters to the whole body contributes with only $4 \mathrm{p}$. cent to the total dose rate received by Gammarus of the Hudson River at Indian Point. However, in terms of dose equivalent, the natural sources (internal plus external) would contribute with more than $75 \mathrm{p}$. cent of the total dose to Gammarus, because of the biological effects of high LET radiation that make the dose from internally emitted alpha particles at least as important as those from background gamma plus beta radiation.

Further studies on the dosimetry of marine organisms of the first two trophic levels should be encouraged because the amount of data available is meager, but there are in the literature conflicting ideas on radioresistance of marine organisms $[2,17]$.

\section{ACKNOWLEDGEMENT}

This research project has been carried out with the support of the National Institute of Environmental Health Science, NIEHS Grant ES 00260. One of the authors, A.S.P., has received a fellowship from CAPES-MEC.

\section{REFERENCES}

[1] Bousfield E. L., Shallow-water gammaridean amphipoda of New England. Ithaca, Cornell University Press, 1973, 1-312.

[2] Bowen V. T., Olsen J. S., Osterberg C. L. and Rivera J. Ecological interaction of marine radioactivity. In: Radioactivity in the marine environment. Washington, National Academy of Sciences, National Research Council, 1971, 200-222.

[3] Cherry R. D. Alpha radioactivity of plankton. Nature, 1964, 203, 139-143.

[4] Eisenbud, M. Environment radioactivity, 2nd ed. New York, Academic Press, 1973, $1-542$.

[5] Folsom T. R. and Harley J. H. Comparison of some natural radiation received by selected organisms. In: The effects of atomic radiation on oceanography and fisheries. Washington, National Academy of Sciences, National Research Council Publication no. $551,1957,28-33$.

[6] HARLEY N. H. Spatial distribution of alpha dose based on energy absorption measurements. Ph. D. Thesis, New York University, 1971.

[7] International Commission on Radiological Protection, I.C.R.P. Evaluation of radiation doses to body tissues from internal contamination due to ocupational exposures. I.C.R.P. Publication 10. Oxford, Pergamon Press, 1968, p. 83. 
[8] LAUER et al. Hudson River ecosystem studies; effects of entrainment by the Indian Point power plant on biota of Hudson River estuary. Report for Consolidated Edison Company, New York, 1973, 1-258.

[9] Lederer C. M., Hollander J. M. and Perlman I. Table of isotopes, 6th ed. London, John Wiley and Sons, 1967, 1-594.

[10] LENTSCH, J. W. The Fate of gamma-emitting radionuclides released into the Hudson River estuary and an evaluation of their environmental significance. Ph. D. Thesis, New York University, 1974.

[11] Loevinger R., Holt J. G. and Hine G. J. Internally administered radioisotopes. In: Radiation dosimetry (G. J. HiNe and G. L. Brownell, Eds.). New York, Academic Press, 1956, 801-873.

[12] Marinelli L. D., Quimby E. H. and Hine G. J. Dosage determination with radioactive isotopes, II-Practical considerations in therapy and protection. Amer. J. Roentgenol. 1948, 59, 260-281.

[13] Martin M. J. and BlicherT-Toft P. H. Radioactive atoms, Auger-Electron, $\alpha-, \beta-$, $\gamma$-, and X-ray data. Nuclear Data Tables, 1970, A-8, 1-198.

[14] Paschoa A. S. The natural radiation dose from radium to Gammarus in the Hudson River. Ph. D. Thesis, New York University, 1975.

[15] Paschoa A. S., Wrenn M. E. and Eisenbud M. Methodology to study the microdistribution of alpha emitters in zooplankton (to be published).

[16] Paschoa A. S., Wrenn M. E. and Eisenbud M. Dosimetry of natural and man-made alpha emitters in zooplankton (to be published).

[17] Polikarpov, G. G. Radioecology of aquatic organisms. New York, Reinhold, 1966.

[18] Shannon L. V. and Cherry R. D. Radium-226 in marine phytoplankton. Earth Planet. Sc. Letters, 1971, 11, 339-343.

[19] Shannon L. V. Marine alpha-radioactivity of Southern Africa, 1 - Gross alpha activity radiation dose, alpha-spectrum and variations in alpha activity of marine life. South Africa, Division of Sea Fisheries, Investigational Report no. 98, 1972, 1-80.

[20] Templeton W. L., Nakatani R. E. and Held E. E. Radiation effects. In: Radioactivity in the marine environment. Washington National Research Council, National Academy of Sciences, 1971, 223-239.

[21] Woodhead D. S. Levels of radioactivity in the marine environment and the dose commitment to marine organism. In: Radioactive contamination of the marine environment, Seattle, July 10-14, 1972. I.A.E.A., Vienna, 1973, 499-525.

[22] Wrenn M. E., Lauer G. L., Kneip T. J., Jinks S. M., Hairr L. M., Mauro J. and FrIedMan B. Radioecological studies of the Hudson River, Report to Consolidated Edison Company of New York, Inc. New York University Medical Center, 1972, 1-86.

[23] Wrenn M. E., Lauer G. J., Kneip T. J., Jinks S. M., Cook G. B., Losasso T. and PASCHOA A. S. Radioecological studies of the Hudson river, Report to Consolidated Edison Company of New York, Inc. New York University Medical Center, 1973, 1-81.

[24] Wrenn M. E., Jinks S. M., Cohen N. and HaIrR L. M. ${ }^{137}$ Cs and ${ }^{134}$ Cs distribution in sediment, water, and biota of the Lower Hudson River and their dosimetric implications for man. In: 3rd International Congress of the International Radiation Protection Association, Washington D. C., September 9-14, 1973, 279-284.

vol. $14-\mathrm{N}^{\circ} 2$ 